\title{
IMPLEMENTASI POST TO POST PHYSICS ADVENTURE UNTUK MENINGKATKAN KETERAMPILAN BERPIKIR TINGKAT TINGGI SISWA
}

\author{
I Kadek Darsika Aryanta \\ SMA Negeri Bali Mandara, Jl. Air Sanih, Kubutambahan Buleleng,Bali, Indonesia \\ Email: darsikabokir@gmail.com
}

\begin{abstract}
Abstrak
Penelitian tindakan kelas ini bertujuan meningkatkan kemampuan berpikir tingkat tinggi fisika siswa, dan mendeskripsikan tanggapan siswa terhadap penerapan pembelajaran post to post physics adventure (P3A). Metode Penelitian yang digunakan adalah penelitian tindakan kelas. Subjek penelitian ini adalah siswa kelas X MIPA 2 SMA Negeri Bali Mandara tahun pelajaran 2016/2017 semester I yang berjumlah 23 orang terdiri dari 11 siswa laki-laki dan 12 siswa perempuan. Objek penelitian ini adalah kemampuan berpikir tingkat tinggi dan tanggapan siswa. Penelitian ini dilakukan dalam dua siklus pembelajaran, dengan tahapan-tahapan dalam tiap siklus adalah perencanaan, tindakan, observasi/evaluasi, dan refleksi. Kemampuan berpikir tingkat tinggi yang dimaksud adalah skor siswa yang diperoleh dalam mengerjakan tes kemampuan berpikir tingkat tinggi yang berjumlah 10 soal essay. Data tanggapan siswa dikumpulkan dengan menggunakan kuisioner. Penelitian ini dikatakan berhasil jika rata-rata nilai kemampuan berpikir tingkat tinggi siswa 75 , dengan ketuntasan klasikal $85 \%$, dan tanggapan siswa minimal berkategori positif. Data yang telah terkumpul tersebut, selanjutnya dianalisis secara deskriptif. Hasil analisis menunjukkan 1) nilai rata-rata kemampuan berpikir tingkat tinggi siswa pada siklus I sebesar 72,60 dengan ketuntasan klasikal 72\% dan pada siklus II sebesar 78,40 dengan ketuntasan klasikal $88 \%$;2) tanggapan siswa terhadap penerapan P3A dalam pembelajaran fisika adalah dengan skor rata-rata sebesar 84,64 dan berada pada kategori positif.
\end{abstract}

Kata kunci: Post to Post Physics Adventure, Kemampuan berpikir tingkat tinggi

\begin{abstract}
This classroom action research aims to improve students higher-order thinking skills and describes students responses to the application of post-post physics adventure(P3A) learning. The research method used is classroom action research. The subjects of this study were the students of class X MIPA 2 SMA Negeri Bali Mandara in the academic year of 2016/2017 semester I which consisted of 23 people consisting of 11 male students and 12 female students. The object of this study is the ability of high-level thinking and student responses. This study was conducted in two learning cycles, with stages in each cycle being planning, action, observation/evaluation, and reflection. High-level thinking skills in question are the score of students obtained in the test of high-ability thinking skills which amounted to 10 questions essay. Student response data were collected using a questionnaire. This research is said to be successful if the average value of students' high-level thinking ability 75 , with $85 \%$ classical completeness, and student responses are at least positive categorized. The data has been collected, and then analyzed descriptively. The result of analysis shows 1) the average value of the students 'high thinking ability in the first cycle of 72.60 with $72 \%$ classical completeness and in the second cycle of 78.40 with $88 \%$ classical completeness; 2) the students' responses to the application of $\mathrm{P} 3 \mathrm{~A}$ in physics learning is with an average score of 84.64 and is in the positive category.
\end{abstract}

Keywords: Post to Post Physics Adventure, High order thinking skills

\section{Pendahuluan}

Berbagai upaya telah dilakukan oleh pemerintah untuk meningkatkan kualitas pendidikan di Indonesia. Upaya-upaya yang telah dilakukan oleh pemerintah diantaranya, perubahan kurikulum dari Kurikulum 2006 menjadi Kurikulum 2013, peningkatan kesejahteraan guru sebagai penghargaan kepada guru karena melaksanakan tugasnya dengan lebih baik, perbaikan sarana dan prasarana sekolah dengan program BOS, mengadakan sertifikasi untuk penjaminan mutu pengajar, pemberdayaan musyawarah guru mata pelajaran (MGMP), mengadakan seminar-seminar nasional bidang pendidikan, serta berbagai upaya lainnya.

Harapan ini ternyata tidak sesuai dengan kenyataan yang dialami oleh siswa-siswa di SMAN Bali Mandara. Indikasi ini berawal dari cukup banyaknya siswa-siswa SMAN Bali Mandara yang mengalami kesulitan menyelesaikan masalah terkait materi pelajaran fisika sehingga cukup banyak di antara mereka yang sering menanyakan masalah tersebut kepada peneliti. Ironisnya lagi, permasalahan-permasalahan yang ditanyakan dan sulit mereka selesaikan sebenarnya sudah diajarkan di sekolah. Dari fakta ini juga terungkap adanya kesenjangan antara keterampilan berpikir tingkat tinggi yang tercantum pada laporan keterampilan berpikir tingkat tinggi siswa 
dan kemampuan yang mereka miliki. Setelah ditelusuri lebih mendalam, ternyata sebagian besar siswa SMAN Bali mandara tersebut juga menunjukkan aktivitas belajar yang relatif rendah pada mata pelajaran fisika. Faktafakta ini secara tidak langsung telah menunjukkan adanya kesenjangan antara harapan pemerintah mengenai peningkatan kualitas pendidikan terutama mata pelajaran fisika dan kenyataan yang sebenarnya terjadi di lapangan.

Adanya kesenjangan antara harapan dan kenyataan ini menggugah keinginan peneliti untuk menyelidiki lebih jauh permasalahan yang dialami siswa-siswa kelas X MIPA 2. Berdasarkan hasil studi awal yang telah dilakukan terhadap keterampilan berpikir tingkat tinggi fisika siswa kelas X MIPA 2, terungkap bahwa ketercapaian keterampilan berpikir tingkat tinggi untuk aspek pemahaman konsep dan penerapannya adalah seperti data yang disajikan dalam Tabel 1.1.

Tabel 1.1 Nilai Keterampilan berpikir tingkat tinggi Fisika Siswa Kelas X MIPA SMAN Bali Mandara Semester 1 Tahun Pelajaran 2016/2017

\begin{tabular}{lrr}
\hline \multicolumn{1}{c}{ Deskripsi } & \multicolumn{2}{c}{ Kelas } \\
& X MIPA 1 & X MIPA 2 \\
\hline Tertinggi & 100 & 92.5 \\
Terendah & 57.5 & 22.5 \\
Standar Deviasi & 11.66 & 20.3 \\
Ketuntasan Klasikal (\%) & 75 & 41.7 \\
Rata-Rata & 84.9 & 68.8 \\
\hline
\end{tabular}

Rendahnya keterampilan berpikir tingkat tinggi dan aktivitas siswa kelas X MIPA 2 diperkirakan sebagian besar disebabkan oleh rendahnya kualitas pembelajaran fisika. Hal ini didapatkan dari hasil refleksi diri yang dilakukan oleh guru pengajar terhadap kualitas pembelajaran sebelumnya.

Pertama, berdasarkan hasil refleksi diri diketahui bahwa dalam pembelajaran guru menggunakan strategi pembelajaran kooperatif dan siklus belajar, namun ternyata belum semua siswa terlibat dalam proses pembelajaran. Hal ini disebabkan karena ketidak-konsistenan guru dalam menerapkan strategi tersebut. Permasalahan tersebut teramati saat pembelajaran, hanya sebagian kecil siswa yang mau berpartisipasi dalam proses pembelajaran. Sedangkan siswa yang lain lebih berperan sebagai pendengar dari pada partisipan.

Kedua, rendahnya pemahaman siswa terhadap konsep pelajaran fisika serta rendahnya aktivitas siswa, yang dikarenakan pembelajaran masih seputar materi yang ada di buku, walaupun dalam pembelajaran sudah menggunakan kelompok-kelompok belajar. Proses aktif siswa dalam merekonstruksi pengetahuan melalui kegiatan eksperimen di laboratorium juga jarang dilakukan. Padahal fisika merupakan pelajaran yang mementingkan proses dan produk, bukan hanya produk semata. Rendahnya pemahaman siswa akan membuat keterampilan berpikir tingkat tinggi fisika siswa juga menjadi rendah. Pada tahun pelajaran 2016/2017, nilai KKM (kriteria ketuntasan minimal) mata pelajaran Fisika pada kelas X adalah 75. Berdasarkan hasil evaluasi pengajaran yang dilakukan pada semester 1 semua siswa sudah mampu mencapai KKM di raport. Namun, dari ulangan harian yang dilaksanakan pada pokok bahasan Momentum Impuls nilai rata-rata siswa masih sangat rendah yaitu 68,8 padahal ketuntasan siswa minimal 75.

Ketiga, guru belum melaksanakan kegiatan yang benar-benar menantang siswa untuk belajar. Kegiatan belajar yang selama ini dilakukan hanya sebatas di kelas saja. Guru belum memiliki inovasi yang baik dalam melakukan teknik pembelajaran sehingga siswa menjadi cenderung pasif di kelas. Guru belum memberikan suatu yang benar-benar menarik bagi siswa. Guru belum memberikan ruang bagi siswa unutk melakukan kompetisi dan tantanan yang baik bagi siswa. Padahal tantangan dan games yang diterapkan akan mampu meningkatkan aktivitas serta kemampuan keterampilan berpikir tingkat tinggi fisika siswa. Dalam kegiatan belajar mengajar maupun dalam penugasan, siswa cenderung pasif dan menunggu temannya untuk mengerjakan tugas. Dengan menggunakan power point, siswa cenderung hanya sebagai passive learner.

Selain ketiga masalah tersebut, siswa merupakan mahkluk individu yang unik. Siswa merupakan satu kesatuan pikir yang independen dan membutuhkan susasana belajar yang nyamam bagi dirinya. Siswa merupakan mahluk social yang mampu menerima masukan dari teman yang lain dan mampu berinteraksi dengan baik di kelas bersama dengan teman lainnya. Untuk itu, pembelajaran kooperatif sangat tepat dilakukan di kelas X MIPA 2.

Berdasarkan uraian tersebut, maka dapat dikatakan bahwa rendahnya keterampilan berpikir tingkat tinggi dan aktivitas siswa di kelas X MIPA 2 pada mata pelajaran fisika dikarenakan pembelajaran belum mengadopsi keinginan siswa untuk belajar, guru belum menggunakan model pembelajaran yang inovatif, dan kurang memberikan tantangan bagi siswa dalam belajar dan cenderung hanya untuk memenuhi tuntutan kurikulum.

Salah satu pembelajaran yang dapat mengakomodasi keterampilan berpikir tingkat tinggi dan aktivitas siswa kelas X MIPA 2 adalah model pembelajaran post to post physics adventure (P3A). Model ini dipandang sebagai model yang cocok untuk menanggulangi permasalahan rendahnya keterampilan berpikir tingkat tinggit dan aktivitas siswa karena model ini menawarkan sebuah konsep untuk menciptakan pembelajaran dengan 
berorientasi pada upaya pemberdayaan aktivitas siswa melalui turnamen dan peningkatan kooperatif siswa dalam belajar.

Pada pembelajaran fisika menggunakan P3A, siswa akan menjadi aktif dalam belajar dan memaksimalkan fungsi kelompoknya dalam meningkatkan kemampuan memahami konsep fisika. Menurut Hamalik (2005), belajar tidak cukup hanya dengan mendengar dan melihat tetapi harus dengan melakukan aktivitas yang lain diantaranya membaca, bertanya, menjawab, berpendapat, mengerjakan tugas,menggambar, mengkomunikasikan, presentasi, diskusi, menyimpulkan, dan memanfaatkan peralatan. Dalam pembelajaran, guru menyajikan permasalahan fisika dan mendorong siswa untuk mengidentifikasi permasalahan, mencaripemecahan, menyimpulkan hasilnya, kemudian mempresentasikannya. Aktivitas dalam suatu pembelajaran bukan hanya siswa yang aktif belajar tetapi di lain pihak, guru juga harus mengorganisasi suatu kondisi yang dapat mengaktifkan siswa dalam belajar. Sehingga dengan kegiatan P3A.

Berdasarkan deskripsi mengenai karakteristik P3A, keunggulan-keunggulan, dan hasil penelitian tersebut, maka implementasi P3A dapat menjadi salah satu solusi yang tepat untuk mengatasi masalah-masalah yang teridentifikasi di kelas X MIPA 2 tahun pelajaran 2016/2017.

Berdasarkan latar belakang masalah tersebut, maka peneliti merasa perlu melakukan suatu penelitian tindakan yang sifatnya kolaboratif berupa implementasi P3A dalam pembelajaran fisika untuk meningkatkan aktivitas dan keterampilan berpikir tingkat tinggi fisika siswa kelas X MIPA 2 tahun pelajaran 2016/2017.

\section{Metode}

Penelitian ini merupakan penelitian tindakan kelas dengan tindakan berupa penerapan P3A dalam pembelajaran fisika. Subjek dalam penelitian ini adalah siswa kelas X MIPA2 SMAN Bali Mandara tahun pelajaran 2016/2017, banyaknya siswa adalah 23 siswa yang terdiri dari 9 siswa laki-laki dan 14 siswa perempuan. Objek penelitian tindakan kelas ini adalah keterampilan berpikir tingkat tinggi. Penelitian ini dilaksanakan selama 5 bulan, mulai bulan April sampai bulan September tahun 2017.

Penelitian dilakukan di SMAN Bali Mandara pada tahun pelajaran 2016/2017 pada kelas X MIPA2. SMAN Bali Mandara terletak di J1. Air Sanih Desa Kubutambahan, Kec. Kubutambahan Kabupaten Buleleng.

Indikator kinerja dalam penelitian ini dilihat dari peningkatan aktivitas dan keterampilan berpikir tingkat tinggi fisika melalui pembelajaran dengan menggunakan miniature rumah. Indikator keberhasilan direfleksikan dengan:

a. Sebanyak $85 \%$ siswa memperoleh nilai keterampilan berpikir tingkat tinggi $\geq 75$ pada siklus I dan II.

b. Rata-rata keterampilan berpikir tingkat tinggi tiap siklus adalah 75.Nilai 75 merupakan nilai ketuntasan minimal (KKM) mata pelajaran fisika kelas X MIPA 2 SMAN Bali Mandara pada tahun pelajaran 2016/2017.

Penelitian ini dilakukan dengan metode Penelitian Tindakan Kelas terdiri dari 2 siklus. Tindakan dalam setiap siklus saling berkaitan erat. Pembagian materi pada tiap siklus didasarkan pada keterkaitan antara kompetensi dasar dan indikator pencapaian keterampilan berpikir tingkat tinggi siswa. Adapun rincian materi pada masing-masing siklus dapat dilihat pada Tabel 3.2 berikut ini.

Tabel 3.2 Rincian Materi Pada Tiap Siklus

\begin{tabular}{clc}
\hline Siklus & \multicolumn{1}{c}{ Kompetensi dasar } & Waktu \\
\hline I & 3.10 Menerapkan konsep momentum dan impuls, serta hukum kekekalan & $\mathbf{3}$ X 3 JP \\
& momentum dalam kehidupan sehari-hari & \\
& 4.10 Menyajikan hasil pengujian penerapan hukum kekekalan momentum, & \\
misalnya bola jatuh bebas ke lantai dan roket sederhana & \\
& 3.11 Menganalisis hubungan antara gaya dan getaran dalam kehidupan & $\mathbf{3} \mathbf{3}$ JP \\
& sehari-hari & \\
& 4.11 Melakukan percobaan getaran harmonis pada ayunan sederhana \\
dan/atau getaran pegas berikut presentasi hasil percobaan serta makna \\
fisisnya
\end{tabular}

Keterangan 1 Jam Pelajaran $=45$ menit

Langkah-langkah dalam tiap siklus terdiri dari (1) membuat perencanaan tindakan, (2) melaksanakan tindakan sesuai yang direncanakan, (3) melakukan pengamatan terhadap tindakan yang dilakukan, dan (4) merefleksi deskriptif komparatif.

Pada bagian awal, sebelum siklus pertama, terdapat tahap reconnaissance (refleksi awal). Pada tahap ini, dilakukan identifikasi, evaluasi, dan formulasi permasalahan kritis dalam pembelajaran di kelas. Kesepakatan kerjasama antara guru-peneliti terhadap suatu thematic corcern (suatu tema penelitian untuk ditindak) merupakan bagian dari tahap ini. 
Tahap berikutnya adalah pelaksanaan tindakan. Pada penelitian ini, tindakan dilaksanakan dalam dua siklus. Materi pembelajaran untuk setiap siklus disesuaikan dengan yang diterapkan di SMAN Bali Mandara.

Adapun teknik pengumpulan data dan instrumen yang digunakan dalam penelitian ini dapat dilihat pada Tabel 3.3.

Tabel 3.3 Teknik Pengumpulan Data

\begin{tabular}{|c|c|c|c|c|}
\hline No & Jenis Data & $\begin{array}{l}\text { Sumber } \\
\text { Data }\end{array}$ & Instrumen Penelitian & Waktu \\
\hline 1 & $\begin{array}{l}\text { Keterampilan } \\
\text { berpikir tingkat } \\
\text { tinggi }\end{array}$ & Siswa & $\begin{array}{l}\text { Tes Keterampilan berpikir tingkat } \\
\text { tinggi Fisika }\end{array}$ & Setiap Akhir Siklus \\
\hline 2 & Respon Siswa & Siswa & Kuisioner & Di akhr siklus II \\
\hline
\end{tabular}

Semua data kuantitatif dalam penelitian ini dianalisis secara deskriptif. Penyimpulan didasarkan pada indikator peningkatan nilai rata-rata setiap data. Data keterampilan berpikir tingkat tinggi siswa dianalisis secara deskriptif. Ketuntasan keterampilan berpikir tingkat tinggi siswa ditentukan dengan menggunakan Daya Serap Siswa (DSS) dan Ketuntasan Klasikal (KK).

$$
\begin{aligned}
& \text { DSS }=\frac{\text { Nilai yang dicapai siswa }}{\text { Nilai Maksimum }} \times 100 \% \\
& \mathrm{KK}=\frac{\text { Banyak siswa yang tuntas }}{\text { Banyak siswa yang ikut tes }} \times 100 \%
\end{aligned}
$$

Indikator keberhasilan pemahaman konsep yang digunakan dalam penelitian ini yaitu nilai DSS minimal 75\% dan KK minimal 85\%. Jadi, penelitian tindakan ini dikatakan berhasil jika nilai rata-rata pemahaman konsep yang dicapai masing-masing siswa minimal 75,00 dan kelas dikatakan tuntas jika nilai KK $\geq 85$.

Ketuntasan keterampilan berpikir tingkat tinggi siswa ini ditentukan dengan menggunakan ketuntasan klasikal (KK).

$$
\mathrm{KK}=\frac{\text { Banyak siswa yang tuntas }}{\text { jumlah total siswa }} \times 100 \%
$$

Penelitian ini dikategorikan berhasil jika nilai satu kelas dikatakan tuntas jika KK $\geq 85 \%$. Hal ini sesuai dengan kriteria yang ditetapkan oleh SMAN Bali Mandara. Semua analisis data dilakukan secara deskriptif dengan menggunakan bantuan program Microsoft Excel for Windows 2010.

Respon siswa terhadap implementasi P3A dalam pembelajaran Fisika dikumpulkan dengan menggunakan angket respon siswa. Kriteria penilaian respon menggunakan skala Likert dengan masing-masing 5 pilihan yaitu sangat setuju (SS), Setuju (S), Ragu-ragu, Tidak Setuju (TS), Sangat Tidak Setuju (STS). Untuk item respon negatif pemberian skor terbalik dengan item respon positif.

Data respon siswa dianalisis secara deskritif berdasarkan skor rata-rata respon siswa $\left(\bar{X}_{R}\right)$, mean ideal (MI), dan standar deviasi ideal (SDI). Skor rerata $\left(\bar{X}_{R}\right)$ yang diperoleh dari perhitungan dibandingkan dengan kriteria penggolongan yang telah ditetapkan., Penelitian ini dikatakan berhasil jika diperoleh $\bar{X}_{R}$ minimal positif.

\section{Hasil dan Pembahasan}

Distribusi frekuensi dan persentase berdasarkan tingkat penguasaan materi skor kemampuan berpikir tingkat tinggi siswa dibuat berdasarkan konversi nilai absolut skala lima dan berdasarkan data skor pascates yang diperoleh. Distribusi dan persentase tersebut jika dipilah dari model pembelajaran disajikan pada Tabel 4.1.

Tabel 4.1 Distribusi Frekuensi dan Persentase Skor Kemampuan Berpikir tingkat tinggi Siswa

\begin{tabular}{cccccc}
\hline \multirow{2}{*}{ Skor } & \multirow{2}{*}{ Kualifikasi } & \multicolumn{2}{c}{ P3A SIKLUS I } & \multicolumn{2}{c}{ P3A SIKLUS II } \\
& & Fo & Persentase(\%) & Fo & Persentase(\%) \\
\hline $32,0-40,0$ & Sangat Tinggi & 12 & 52 & 15 & 60 \\
$24,0-31,9$ & Tinggi & 6 & 24 & 8 & 32 \\
$16,0-23,9$ & Cukup & 5 & 24 & 2 & 8 \\
$8,0-15,9$ & Kurang & 0 & 0 & 0 & 0 \\
$0,00-7,9$ & Sangat Kurang & 0 & 0 & 0 & 0
\end{tabular}




\begin{tabular}{ccccc}
\cline { 2 - 4 } Jumlah & 23 & 100 & 25 & 100 \\
\hline
\end{tabular}

Keterangan: Fo $=$ frekuensi observasi

Data kemampuan berpikir tingkat tinggi siswa yang diperoleh dari hasil pengerjaan tes kemampuan berpikir tingkat tinggi. Berdasarkan hasil analisis, juga diperoleh nilai kemampuan berpikir tingkat tinggi siswa ( $\bar{X}$ ) 72,64, seperti disajikan pada Tabel 4.2.

Tabel 4.2 Profil Kemampuan Berpikir tingkat tinggi Siswa pada Siklus I dan siklus II

\begin{tabular}{lcc}
\hline \multicolumn{1}{c}{ Aspek } & Siklus I & Siklus II \\
\hline Nilai Tertinggi & 90.00 & 95.0 \\
Nilai Terendah & 40.00 & 55.0 \\
Rata-rata & 72.64 & 78.4 \\
Standar Deviasi & 15.82 & 9.6 \\
Ketuntasan & $72 \%$ & $88 \%$ \\
\hline
\end{tabular}

Perbandingan perolehan kemampuan berpikir tingkat tinggi siswa pada akhir siklus II dengan siklus I untuk masing-masing kategori disajikan pada Gambar 4.1

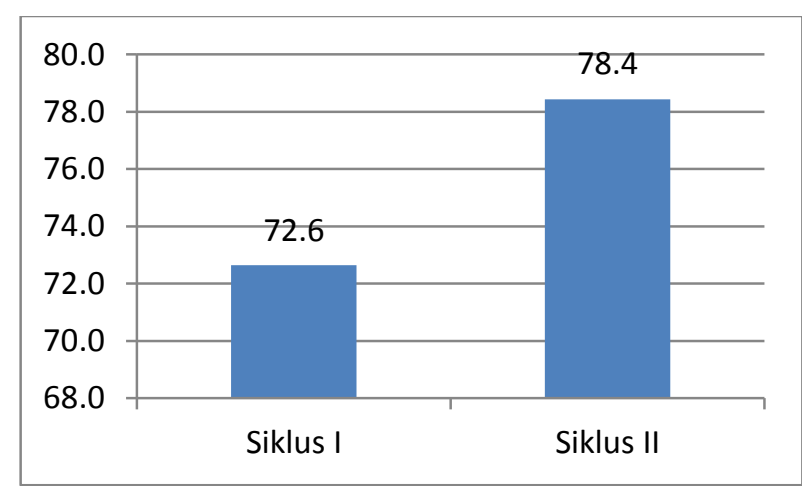

\section{Gambar 4.1 Perbandingan Perolehan Kemampuan Berpikir tingkat tinggi Siswa pada Siklus I dan Siklus II}

Tanggapan siswa terhadap penerapan P3A dalam proses pembelajaran dikumpulkan dengan menggunakan angket tanggapan yang diberikan kepada siswa di akhir siklus II. Berdasarkan analisis skor tanggapan siswa tersebut, didapatkan skor rata-rata siswa sebesar 84,78 dengan standar deviasi 7,67. Data tanggapan siswa yang diperoleh disajikan pada lampiran. Sebaran tanggapan siswa pada masing-masing kategori disajikan pada Tabel 4.3.

Tabel 4.3 Profil Tanggapan Siswa Terhadap Proses Pembelajaran P3A

\begin{tabular}{ccccr}
\hline No & Kelas Interval & Frekuensi & Persentase & Kategori \\
\hline 1 & $20-29$ & 0 & $0,00 \%$ & Sangat Kurang Positif \\
2 & $30-49$ & 0 & $0,00 \%$ & Kurang Positif \\
3 & $50-69$ & 0 & $0,00 \%$ & Cukup Positif \\
4 & $70-89$ & 15 & $60,0 \%$ & Positif \\
5 & $90-100$ & 10 & $40,0 \%$ & Sangat Positif \\
\hline
\end{tabular}

Persentase tanggapan siswa terhadap proses pembelajaran P3A disajikan pada Gambar 4.3 


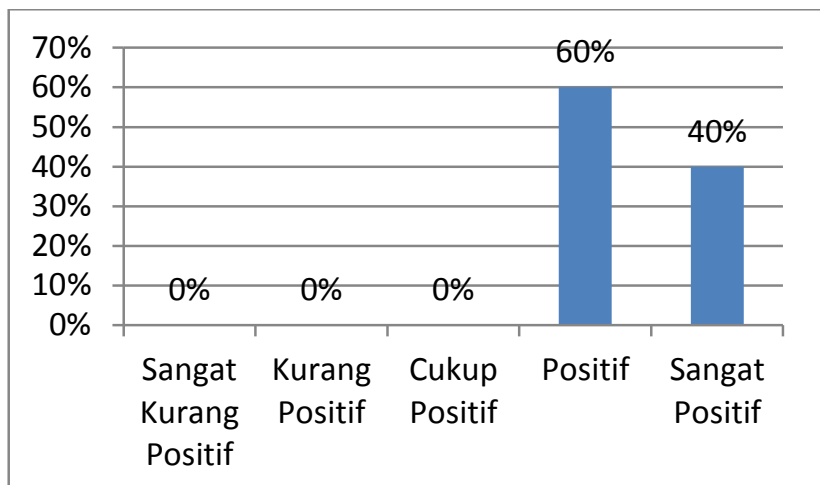

\section{Gambar 4.3 Persentase Tanggapan Siswa Terhadap Proses Pembelajaran}

Berdasarkan kriteria yang telah ditetapkan, didapatkan rata-rata tanggapan siswa kelas X MIPA 2 SMA Negeri Bali Mandara berada pada kategori positif.

Berdasarkan penelitian yang telah dilaksanakan selama dua siklus di kelas X MIPA 2 SMA Negeri Bali Mandara tahun pelajaran 2016/2017 pada semester II untuk pokok bahasan Momentum Impuls dan Hukum Newton. Hasil penelitian menunjukkan adanya peningkatan kemampuan berpikir tingkat tinggi siswa melalui penerapan P3A dalam pembelajaran fisika

Dari hasil penelitian ini terungkap bahwa keterampilan berpikir tingkat tinggi siswa meningkat dengan melihat ciri-ciri kemampuan berpikir tingkat tinggi seperti, siswa sudah mampu menentukan kredibilitas suatu sumber atau bahan untuk dijasikan sebagai bahan argumentasi dalam melakukan diskusi di tahap asosiasi konsep dalam P3A. Disamping itu, pada tahap tahap pembelajaran saintifik, siswa dilatih untuk mengetahui dan membedakan antara sumber yang relevan dari yang tidak relevan. Pada pandangan ini terlihat dari tahap mengomunikasikan hasil dari asosiasi dan elaborasi sumber belajar mereka. Selain itu, siswa juga sangat terlihat mampu membedakan fakta dari penilaian dan mengevaluasi asumsi yang tidak terucapkan.

Kemampuan berpikir tingkat tinggi siswa merupakan skor yang diperoleh siswa setelah mengerjakan tes kemampuan berpikir tingkat tinggi di akhir siklus. Tes kemampuan berpikir tingkat tinggi disesuaikan dengan materi yang diajarkan di kelas dengan memperhatikan SK dan KD disetiap topik. Tes kemampuan berpikir tingkat tinggi tahap 1 dilaksanakan di akhir siklus I dengan topik Momentum Impuls dan tes kemampuan berpikir tingkat tinggi tahap II dilaksanakan di akhir siklus 2 dengan topik Gerak Harmonik dan Penerapannya.

Secara kualitatif, penelitian ini telah mengungkapkan gambaran kemampuan berpikir tingkat tinggi para siswa kelas X MIPA 2 SMA Negeri Bali Mandara hasil penelitian menunjukkan bahwa secara deskriptif kelompok siswa yang mengikuti pembelajaran dengan P3A menunjukkan kemampuan berpikir tingkat tinggi yang lebih tinggi pada siklus I dengan siklus II.

Berdasarkan hasil refleksi I, maka dilakukan upaya perbaikan pada siklus II. Implikasinya, nilai rata-rata kemampuan berpikir tingkat tinggi siswa mengalami peningkatan sebesar 5,80 poin. Hasil temuan ini menunjukkan bahwa penerapan P3A dapat meningkatkan kemampuan berpikir tingkat tinggi siswa.

Hasil penelitian ini tampaknya konsisten dengan penelitian yang dilakukan (Hotimah \& Motlan, 2012) yang menunjukkan bahwa hasil belajar siswa yang diajarkan dengan menggunakan model pembelajaran kooperatif tipe TGT lebih tinggi dibandingkan dengan hasil belajar siswa yang diajarkan dengan model Direct Instruction. Hal ini juga diperkuat oleh penelitian yang dilakukan oleh (Rochmawati \& Sunarno, 2013) yang menyatakan bahwa terdapat pengaruh pembelajaran menggunakan TGT melalui teka teki silang dan kartu terhadap prestasi kognitif namun tidak terdapat pengaruh pembelajaran menggunakan TGT melalui teka teki silang dan kartu terhadap prestasi afektif dan juga terdapat pengaruh kemampuan verbal tinggi dan rendah terhadap prestasi kognitif maupun afektif. Hasil penelitian yang dilakukan oleh (Haya et al., 2014) juga menunjukkan bahwa pembelajaran dengan menggunakan teknik game dapat menarik perhatian siswa, melatih untuk berpikir kritis dan kreatif, serta dapat mendorong untuk belajar mandiri.

Walaupun penelitian ini konsisten dengan hasil-hasil penelitian sebelumnya, namun terdapat dua pertanyaan yang memerlukan pembahasan lebih lanjut terkait dengan pencapaian kemampuan berpikir tingkat tinggi. Pertama, secara teoretik dan operasional empiris mengapa dalam pencapaian kemampuan berpikir tingkat tinggi, model pembelajaran berbasis masalah lebih unggul dibandingkan dengan model pembelajaran pemecahan masalah. Kedua, mengapa secara statistik deskriptif model pembelajaran berbasis masalah dalam pencapaian kemampuan berpikir tingkat tinggi belum dapat mencapai kategori sangat baik.

Pembahasan atas pertanyaan pertama beranjak dari komparasi secara teoretik dan operasional empiris dari P3A. Secara teoretik jika dilihat dari filosofisnya, P3A meletakkan dasar pada filosofis pendidikan John Dewey, di mana siswa akan belajar dengan baik apabila mereka terlibat secara aktif dalam segala kegiatan di kelas dan berkesempatan untuk menemukan sendiri . Di samping itu, P3A didasari pada motivasi intrinsik yang sesuai 
dengan paham konstruktivisme tentang pembelajaran, di mana siswalah yang seharusnya mengalami pembelajaran sedangkan guru hanya sebagai mediator dan fasilitator.

Secara operasional empiris, P3A menyajikan materi pelajaran yang diawali dengan penyajian masalah nyata yang bersifat tidak terstruktur. Masalah yang diberikan merupakan masalah yang belum terdefinisikan, sehingga siswa dituntut untuk menganalisis masalah tersebut secara cermat, mengidentifikasi apa yang mereka ketahui dari masalah, yang ingin mereka ketahui dan yang harus mereka cari. Dengan memberikan masalah nyata di awal pembelajaran, maka siswa mengetahui tujuan mereka mempelajari materi ajar tersebut. Penyajian masalah ini dapat meningkatkan motivasi siswa. Dengan motivasi yang tinggi, siswa lebih tertarik untuk memecahkan masalah-masalah yang terdapat pada LKS sehingga informasi yang didapatkan akan lebih tertata rapi dalam struktur kognitif siswa. Motivasi intrinsik siswa terlihat ketika mereka melakukan strategi pemecahan masalah di mana dalam LKS hanya disediakan masalah nyata yang bersifat tidak terstruktur sedangkan rumusan masalah, analisis masalah dan jawaban sementara (perumusan hipotesis) dilakukan sendiri oleh siswa dalam kelompok belajar yang telah dibentuk.

Jika dilihat dari sintaks atau langkah-langkah pembelajarannya, P3A lebih menekankan pada aktivitas siswa dan bersifat student-centered. Siswa bertanggung jawab penuh terhadap kegiatan pembelajaran dan siswa diberikan kesempatan untuk mengembangkan aktivitas dan pola pikirnya secara optimal melalui langkah-langkah utama di antaranya: (1) mengamati permasalahan, (2) menanyakan permasalahan dengan guru atau teman sejawat, (3) mengumpulkan informasi atau mencoba melakukan sesuaitu dalam eksperimen, (4) mengasosiasikan hasil eksperimen, dan (5) mengomunikasikan hasil ekperimen atau hasil pengamatan. Pembelajaran fisika dengan menggunakan P3A yang diawali dengan penyajian masalah dan dilanjutkan dengan analisis masalah oleh siswa dalam kelompok-kelompok kecil sampai dengan pada penemuan fakta, teori, konsep, ataupun prinsip-prinsip fisika untuk menyelesaikan masalah merupakan wahana yang baik dalam mengasah dan melatih kemampuan berpikir siswa. Kemampuan berpikir sangat diperlukan dalam menganalisis, memecahkan masalah dan mengambil keputusan.

Pada penelitian tindakan kelas ini, P3A secara deskriptif mampu meningkatkan kemampuan berpikir tingkat tinggi siswa. Hal ini disebabkan pada diri siswa terjadi perubahan paradigma dalam hal metode belajar, di mana siswa yang biasanya belajar secara konvensional diganti dengan menerapkan P3A. Siswa yang pada mulanya hanya menunggu perintah dari gurunya untuk belajar yang seketika berubah saat mulai diterapkan P3A. Oleh karena itu, siswa tidak mengerahkan semua kemampuan dan interaksinya untuk melakukan diskusi untuk memecahkan permasalahan yang diberikan secara optimal. Faktor lain yang diduga mempengaruhi adalah rentang waktu kegiatan pembelajaran yang relatif singkat.

Temuan dalam penelitian tindakan kelas ini memberikan petunjuk bahwa P3A memiliki keunggulan dalam hal meningkatkan kemampuan berpikir tingkat tinggi. Berdasarkan hal tersebut maka implikasi yang dapat diberikan adalah kemampuan berpikir tingkat tinggi siswa dapat ditingkatkan dengan menerapkan P3A. Pada P3A, siswa aktif terlibat dalam kegiatan pembelajaran, senantiasa dilatih untuk menganalisis dan memecahkan masalah kontekstual. Materi pelajaran dalam model pembelajaran berbasis masalah dikemas dalam bentuk masalah yang berkaitan dengan lingkungan siswa. Hal ini dapat menimbulkan motivasi intrinsik siswa untuk lebih bertanggung jawab dalam kegiatan pembelajaran. Pada pembelajaran berbasis masalah, guru berperan sebagai fasilitator dan mediator.

Fase fase pembelajaran saintifik sangat penting untuk dikaji dalam peningkatan kemampuan berpikir tingkat tinggi siswa. Pada tahap eksperimen dan pengamatan, terlihat jelas bahwa siswa sangat serius dalam menanggapi masalah dan kemampuan siswa tersebut terlihat dari bagaimana siswa tersebut antusias dengan apa yang menjadi topik permasalahannya. Hasil yang diperoleh sejalan juga dengan penelitian yang dilakukan oleh Khoirifah et al (2013) yang menyatakan bahwa siswa yang belajar dengan pembelajaran yang menyediakan permasalahan dan melakukan pengamatan memiliki kemampuan berpikir tingkat tinggi yang lebih baik dari pembelajaran konvensional. Dengan melakukan eksperimen dan pengamatan, siswa dituntut untuk berpikir tingkat tinggi dalam menyelesaikan masalah sesuai tahap-tahap dalam pembelajaran saintifik yang dilakukan secara berdiskusi dengan berbantuan modul, sehingga siswa merasa senang dalam pembelajaran. Dalam menyelesaikan masalah, siswa bekerja secara mandiri guru hanya sebagai fasilitator saja, dengan begitu siswa akan selalu berpikir bebas untuk memecahkan masalah tersebut.

Meningkatnya kemampuan berpikir tingkat tinggi ini tidak lepas dari kemampuan siswa untuk mengasosiasi dan mengamati suatu permasalahan sebagai hasil pengamatan. Meningkatnya kemampuan mengamati dan kemampuan berpikir tingkat tinggi sejalan dengan penelitian yang dilakukan oleh Dwijananti \& Yulianti (2010) yang menyatakan bahwa kemampuan berpikir tingkat tinggi mahasiswa yang dapat dikembangkan pada model pembelajaran problem based instruction adalah: mengklasifikasi, mengasumsi, memprediksi, menghipotesis, mengevaluasi, menganalisis, dan membuat kesimpulan. Hal ini sangat sejalan dengan kemampuan yang dapat ditingkatkan dari 5 langkah pembelajaran saintifik.

Hasil temuan ini sejalan dengan hasil penelitian yang dilakukan oleh (Trimaryana \& Retinofa, 2016). Hasil penelitian menunjukkan bahwa kelompok siswa yang diberi pembelajaran dengan menggunakan permainan Rorodan dapat meningkatkan motivasi dan pemahaman konsepnya sebanyak 15,5\%. Hal tersebut 
mengindikasikan bahwa penerapan P3A dalam pembelajaran fisika dapat diimplementasikan untuk meningkatkan pemahaman dan kemampuan berpikir tingkat tinggi siswa. Walaupun peningkatan yang diperoleh tidak tinggi tetapi secara kriteria keberhasilan penelitian ini sudah dikatakan berhasil. Penelitian mengenai permainan di dalam kelas juga dilakukan oleh (Asrodin, 2008) mampu meningkatkan motivasi belajar siswa. Motivasi belajar matematika siswa sebelum dilakukan tindakan berada pada kategori rendah (sebesar 35.19\%), pada siklus I meningkat menjadi pada kategori tinggi (sebesar 75\%) dan pada siklus II meningkat menjadi berada pada kategori sangat tinggi (sebesar $80.35 \%$ ).

Tanggapan siswa diperoleh dari penyebaran kuesioner pada akhir siklus II, yang terdiri dari 20 item pernyataan positif maupun negatif. Tujuan pemberian kuisioner tanggapan tersebut untuk mendeskripsikan tanggapan siswa terhadap penerapan P3A dalam pembelajaran fisika di kelas X MIPA 2 SMA Negeri Bali Mandara. Berdasarkan analisis yang telah dilakukan terhadap tanggapan yang diberikan siswa ditemukan bahwa tanggapan siswa memberikan skor rata-rata sebesar 84,78 dan berada pada kategori positif. Siswa setuju dan senang dengan penerapan model pembelajaran perubahan konseptual selama proses pembelajaran fisika, karena tidak membosankan dan setiap usaha maupun penyampaian pendapat yang mereka lakukan merasa dihargai.

\section{Simpulan dan Saran}

Berdasarkan hasil penelitian yang dilakukan maka dapat disimpulkan sebagai berikut.Implementasi Post to Post Physics Adventure (P3A) dapat meningkatkan kemampuan berpikir tingkat tinggi siswa kelas X MIPA 2 SMAN Bali Mandara Tahun Pelajaran 2016/2017 dan tanggapan siswa kelas X MIPA 2 terhadap implementasi P3A dalam pembelajaran fisika pada kategori positif.

Implementasi P3A dapat digunakan sebagai salah satu alternatif pendekatan pembelajaran untuk meningkatkan kemampuan berpikir tingkat tinggi siswa. Dalam mengimplementasikan P3A, sebaiknya guru melakukan persiapan mengajar dengan baik misalnya dengan merancang pembelajaran di kelas yang dilakukan berkelompok dan diikuti dengan praktik di lapangan, mengoptimalkan diskusi kelas, serta membelajarkan siswa dalam merefleksi hasil pembelajarannya di setiap pertemuan, dan mendorong siswa untuk secara sadar mampu mengupayakan peningkatan kualitas pembelajarannya. Dalam pelaksanaan games, sebaiknya bahan yang digunakan untuk games yang dipahami lebih dahulu oleh siswa. Begitu juga hadiah yang digunakan dalam penghargaan kelompok sebaiknya di share juga ke kelompok yang tidak mendapat juara untuk menghargai hasil kerja siswa.

\section{Daftar Rujukan}

Asrodin. (2008). Penggunaan Musik Dan Model Pembelajaran Kooperatif Tipe Team Game Tournaments (TGT) dalam upaya meningkatkan aktivitas dan motivasi belajar matematika siswa kelas $v$ sd muhammadiyah blawong ii bantul. Universitas Islam Negeri Sunan Kalijaga Yogyakarta.

Haya, F. D., Waskito, D. S., Pd, M., Fauzi, A., Fisika, P., Keguruan, F., \& Pendidikan, D. I. (2014). Pengembangan Media Pembelajaran Gasik (Game Fisika Asik) Untuk Siswa Kelas VIII Sekolah Menengah Pertama. Jurnal Pendidikan Fisika, 2(11).

Hotimah, H., \& Motlan. (2012). Efek Penerapan Model Pembelajaran Kooperatif Tipe Team Games Tournament (TGT) Terhadap Motivasi Belajar Siswa Dan Hasil Belajar Fisika Pada Konsep Listrik Statis Di Sekolah Menengah Menengah Pertama. Jurnal Online Pendidikan Fisika ISSN 2301-7651, 1(2), 73-82.

Rochmawati, W., \& Sunarno, W. (2013). Tournament Melalui Teka Teki Silang Dankartu Ditinjau Dari Kemampuan Verbal Dan. Jurnal Inkuiri, 2(1), 66. Retrieved from http://jurnal.fkip.uns.ac.id/index.php/sains\%0apembelajaran

Trimaryana, O. F., \& Retinofa, R. R. (2016). The Application of Traditional Game Rorodaan as Learning Tool in Physics Subject: Force and Movement to Improve Learning Results. Journal of Physics: Conference Series, 739(1). https://doi.org/10.1088/1742-6596/739/1/012093 